Universidade Tecnológica Federal do Paraná - UTFPR

Campus Ponta Grossa - Paraná - Brasil

ISSN: 1981-3686/v. 05, n. 01: p. 356-366, 2011

D.O.I: $10.3895 / \mathrm{S} 1981-36862011000100011$

\section{Revista Brasileira de Tecnologia \\ Agroindustrial}

\title{
APPLICATION OF BACTERIAL CELLULOSE CONSERVATION OF MINIMALLY PROCESSED FRUITS
}

\section{APLICAÇÃO DE CELULOSE BACTERIANA NA CONSERVAÇÃO DE FRUTAS MINIMAMENTE PROCESSADAS}

\author{
Denise Milléo Almeida ${ }^{1}$, Rosilene Aparecida Prestes ${ }^{2}$, Adenise Lorenci Woiciechowski $^{3}$, \\ Gilvan Wosiacki ${ }^{4}$ \\ ${ }^{1,3}$ Federal University of Paraná - Curitiba - Brazil denisemilleo@ hotmail.com; adenise@ufpr.br \\ ${ }^{2,4}$ State University of Ponta Grossa - Ponta Grossa - Brazil raprestes@yahoo.com.br; wosiacki@uol.com
}

\begin{abstract}
The consumer by fresh food such as fruits has increased in the last decades and the minimally processed has come to attend this demand. The focus of this paper is to evaluate the application of celluloses biofilm in the conservation of minimally processed fruits. It was followed a $\left(\begin{array}{lll}2 & x & 5\end{array}\right)$ factorial design, with two treatments (with and without cellulose) and five periods of storage (0, 48, 96, 144 and 192h). Strawberries cv. Festival (intact) and apples (four sliced) cv. Gala were used as samples for the biofilm application. The output variable were the fruit mass, the total titratable acidity (ATT), soluble solids total (SST), the relation SST/ATT, $p H$, firmness, phenolic compounds and vitamin $C$. Strawberries test as compared with the control kept the fresh mass until 120h, decrease were observed in SST (5.8\%), pH (1.5\%), firmness (18.4\%), vitamin $C(2.2 \%)$ and increase in the concentration of phenolic compounds (3.4\%). Apples test compared to the control show decrease in weight loss (10.5\%), increase in ATT (15.6\%) of SST (8.1\%), TSS / TTA (6.7\%), firmness (18.8\%) and vitamin C (22.2\%). The bacterial cellulose was efficient maintaining quality of the strawberries and apples in the quality attributes of fresh mass, ATT, SST, firmness and vitamin $C$, as a natural preservative. The application of bacterial cellulose biofilm offers using potential in fruits minimally processed, kept by combine methods (biofilm and cooling), maintaining the quality by physical and chemical stability of the products.
\end{abstract}

Key-words: strawberry; apple; bacterial cellulose; quality.

\section{Introduction}

The consumers demand for fresh and convenient food has increased greatly in the last decades. In this scene appears minimally processed food, which binds practicality and convenience, providing save time in the food preparation (GARCIA, 2009; SANTANA, 2008). In this process, the fruits and vegetables are perishable and show fast quality degradation, due mainly to the mechanical stress in the tissue surface, causing by the selection, cleaning, wash, peeling, cut, sanitization, drying and packing operations (MORETTI, 2007). 
The different alternative treatments postharvest has been used in the microorganism control, as well as, in the delay or prevention of the fruits maturity. The application of this films and covers has a promise use in the market by the numerous vantages that it shows. These aspects refer to the biodegradable characteristics, addictives incorporation, delayed water loss, lower cost, and a modified atmosphere in the inner product; delayed in the fruits maturity, decrease in the disease incidence and in superficial abrasion during handling (CHITARRA and CHITARRA, 2005).

Microbial polysaccharides show as new perspectives to enhance the barrier improving the mechanical properties of biofilm. Produced by the Acetobacter xyllinum, cellulose has permeability to liquids and gas, high chemical purity, crystallinity, high tension force, elasticity, durability, biodegradability, nontoxic and non-allergic. In the food area, it can be applied as an addictive, emulsifier, dietary fiber and edible preservative, a barrier against the bacterial growth (MATEOS, 2007; PACHECO, 2004).

This paper has the objective to evaluate the application of celluloses biofilm in the conservation of minimally processed fruits.

\section{Material and Methods}

\section{Material}

Bacterial cellulose obtained in the fermentative process with the Acetobacter xylinum (ATCC 23769), strawberry cv. Festival and apple cv. Gala were used as perishable food, from the state of Paraná - Brazil).

\section{Methods}

Figure 1 - Fruits coated with bacterial cellulose: (a) strawberry (b) apple

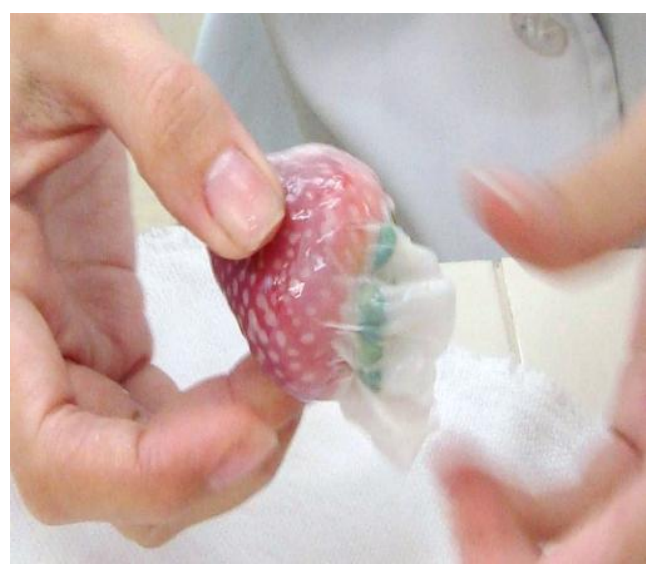

(a)

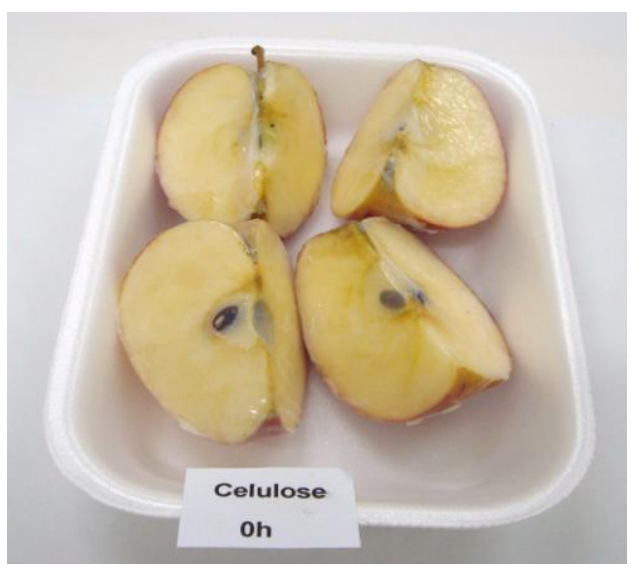

(b)

Preparation of biofilm coated minimal processed fruit 
The bacterial cellulose pellicle was heated in boiling water during $10 \mathrm{~min}$, following successive washes, treatment with $\mathrm{NaOH} 0.1 \mathrm{~mol}^{-1^{-1}}$ at $90^{\circ} \mathrm{C}$ by $30 \mathrm{~min}$ (WU and LIA, 2008), and after exhaustive washing was pressed to remove excess water. Sanitized fruit was treated with 150 $\mathrm{mg} \mathrm{l}^{-1}$ sodium hypochlorite during $15 \mathrm{~min}$ and after rinsing with tap water and drying at room temperature with circulating air during one hour. To completely coat the strawberries (intact) and apple (four slices) a $0.02 \mathrm{~mm}$ thickness pellicle was used cover occur in all the extension (Figure 1 $\mathrm{a}$ and $\mathrm{b}$, respectively).

\section{Evaluation of the bacterial cellulose pellicle efficiency}

The output variables use to evaluate the biofilm efficiency were as follows:

Mass - The gravimetric difference between initial and final weight, expressed as percentage.

Total Titratable Acidity (TTA) - The among of acid determined by titration with $\mathrm{NaOH} 0,1$ mol. $1^{-1}$ until $\mathrm{pH} 8.33$, with results expressed in mg. $\mathrm{l}^{-1}$ of citric acid and mg. $\mathrm{l}^{-1}$ of malic acid to strawberry and apple, respectively.

Soluble Solids Total (SST) - Determined according to the refratometry index with the measure made in a refractometer (ABBE 2 WAJ- 970139 - São Paulo, Brazil), calibrated with distilled water and corrected for temperature of $20^{\circ} \mathrm{C}$, and scaling as Brix degree ( ${ }^{\circ}$ Brix).

Ratio SST/ATT - The ratio is a pure number.

$\mathrm{pH}$ - The pH was measured with the digital pHmeter bench (Pec-2MP, Tecnal Company São Paulo, Brazil), directly submerged into the juice.

Firmness - It was measured with the penetrometer bench (Penetrometer tester mod FT 011 Wagner Instruments Company, Greenwich, Connecticut state, United States of America - USA), with steal tip of diameter of $8 \mathrm{~mm}$ to the strawberry and $6 \mathrm{~mm}$ to the apple, calibrated before the tests. Two measures in each fruit, at the equatorial region, were done and the results, expressed in Kgf.

Phenolic Compounds - They were quantified with Folin-Ciocalteau method (SINGLETON and ROSSI, 1965) expressed as catechin in mg..$^{-1}$.

Vitamin C - The content of vitamin C was determined by the Tillmans (DCFI) method (COX and PEARSON, 1962), being the results expressed as ascorbic acid, mg. $1^{-1}$ of the fruit

\section{Data analysis}

The statistical design with a set of 10 runs from the factorial 2 x 5 totally andomized, being two treatments (with and without cover) and five storage times (0, 48, 96, 144, 192 hours), with three repetitions. The data were submitted to ANOVA at $95 \%$ of probability. 


\section{Results and Discussion}

Significant differences in the values of average mass loss, between the treatments and during the storage period, on both fruits, were observed. The F test corroborates with the values of probability $(P)$ and shows statistical significance in the variable storage time for predictive purposes. The mass loss showed a linear relationship tendency with the storage time in both treatments and fruits. When the strawberries loose $6 \%$ of their weight in the trees they are no longer marketable (MALGARIM et al. 2006). In this aspect it was checked that strawberries cover with bacterial cellulose were efficient in the reduction of the weight loss, with average values of $5.7 \%$ until the $120 \mathrm{~h}$ as compared with the blank (without biofilm coat) that could be stored only until $48 \mathrm{~h}$ because at $96 \mathrm{~h}$ they have lost $7.3 \% \pm 1.2$, being without commercial appeal. In the case of Apples, the runs without coating showed almost the same figures as strawberries, of $13.5 \%$, but the runs with coating the averaged value or $10.57 \%$ is higher than the $8.10 \%$ found for strawberries at the end of the experiment (Figure 2).

Figure 2 - Weight loss in strawberries cv. Festival e apple cv. Gala minimally processed, with and without bacterial cellulose, kept at $7{ }^{\circ} \mathrm{C} \pm 2{ }^{\circ} \mathrm{C}$ in $90 \% \pm 5 \%$ of relative humidity (RH).

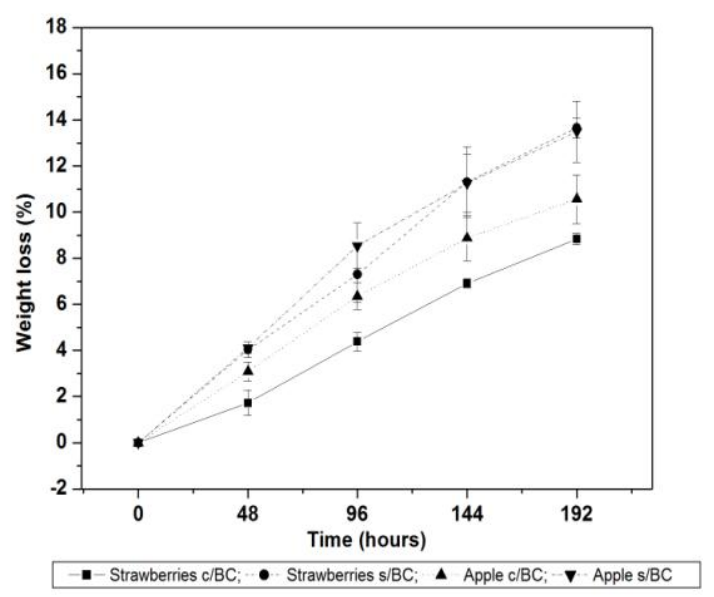

The cover shape promoted significant changes $(\mathrm{p} \leq 0.05)$ in the total titratable acidity medium values, between the strawberries treatments and storage time. In the apples there were not a significant statistically changes $(\mathrm{p} \geq 0.05)$ in any variables. The test $\mathrm{F}$ confirms the values of $P$ and shows significance in predictive purposes only between the strawberry treatments. Strawberries cover with the bacterial cellulose pellicle showed variation from $0.36 \%$ to $0.58 \%$ of citric acid, 
during the storage period, indicating that it was under the acidity of $0.5 \%$ until the $144 \mathrm{~h}$, possibly fruits still unripe. For the samples without cover, the content was from $0.50 \%$ to $0.82 \%$, inside the range found for the ripe strawberries that can change between $0.5 \%$ and $2.3 \%$ of citric acid (PELAYO et al., 2003; CORDENUNSI et al., 2003). The apple, with and without bacterial cellulose cover, shows variation of $0.22 \%$ at $0.25 \%$, respectively, in the concentration of malic acid during storage. Apples without cover had a variation of 0.19 to $0.29 \%$, values in agreement with Instruction Normative $n^{\circ} 1$ of 2000 (BRASIL, 2000) that requires an acidity minimum of $0.15 \%$. The coated apple shows smallest variation percentage, $15.6 \%$ regarding to that without biofilm, with $54 \%$, during the storage period (Figure 3).

Figure 3 - Total Titratable Acidity (ATT) in strawberries cv. Festival e apple cv. Gala minimally processed, with and without bacterial cellulose, kept at $7{ }^{\circ} \mathrm{C} \pm 2{ }^{\circ} \mathrm{C}$ in $90 \% \pm 5 \%$ relative humidity $(\mathrm{RH})$.

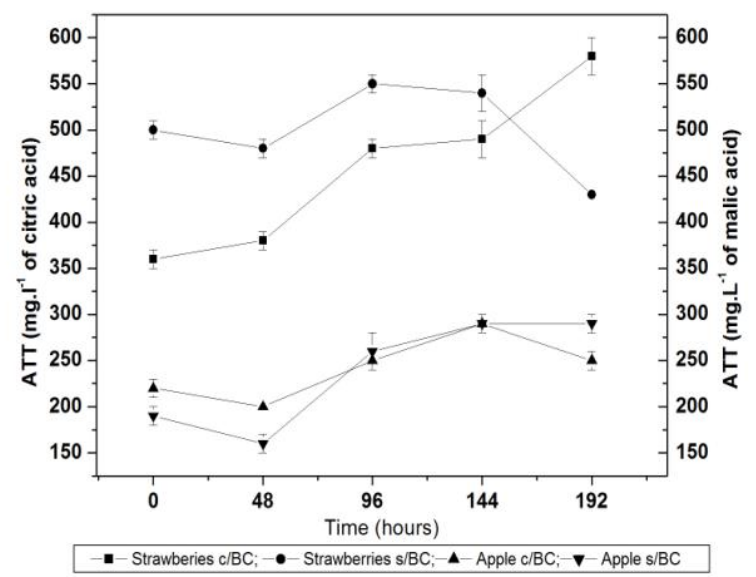

In the coated apple with there was found the smallest oscillation, ca $8.1 \%$, and the noncoated apples was $9.9 \%$, during the storage period (Figure 4).

Figure 4 - Total Soluble solids (SST) in strawberries cv. Festival e apple cv. Gala minimally processed, with and without bacterial cellulose, kept at $7{ }^{\circ} \mathrm{C} \pm 2{ }^{\circ} \mathrm{C}$ in $90 \% \pm 5 \%$ relative humidity $(\mathrm{RH})$.

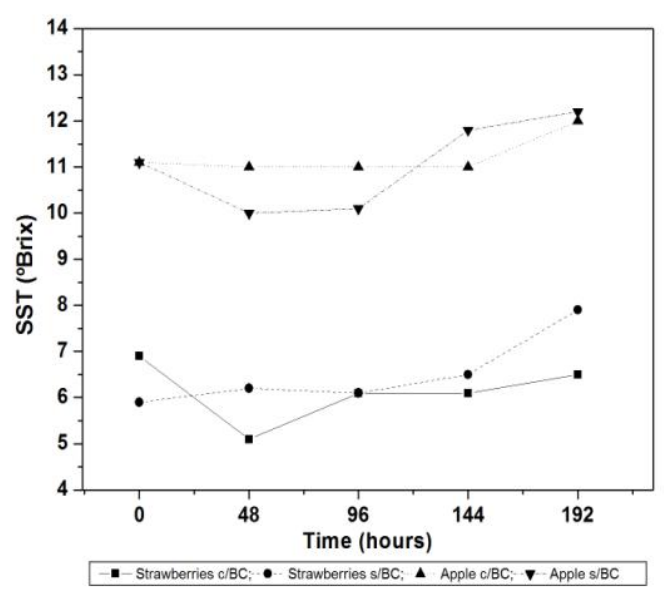


The medium value in the SST content shows that, both in strawberries and apples, there were significant differences $(\mathrm{p} \leq 0.05)$ between the treatments, however, during the storage period this factor does not show any change ( $\mathrm{p} \geq 0.05)$. The test $\mathrm{F}$ corroborates with the values of $P$ and shows statistical significance to the predictive results to the treatment variable, in both fruits. Strawberries with bacterial cellulose cover shows reduction of $5.8 \%$ in the SST content, meanwhile the strawberries without the cover shows increase of 33.9\%. According to Chitarra and Chitarra (2005), the metabolic processes concerning ripening influence directly the total solid soluble amount, probably because of the dissociation of some molecules and structural enzymes and shows the highest soluble solids contents.

It was observed significant differences $(\mathrm{p} \leq 0.05)$ in the medium values of the SST/ATT ratio between the treatments, for both fruits but during the storage period, this factor does not show any change ( $\mathrm{p} \geq 0.05$ ). The test $\mathrm{F}$ corroborates with the values of $P$ and shows statistical significance to the predictive results to the treatment variable, in both fruits. In strawberries, with and without biofilm, the SST/ATT decrease $40.8 \%$ and $18.6 \%$, respectively (Figure 5). This might happen because of the low acidity found in the coated strawberries during the storage, leading to a wrong interpretation of the taste equilibrium. In apples, with and without biofilm, the SST/ATT showed decreases of $6.7 \%$ and $28.6 \%$, respectively, during the storage. These values were close to that found by RIZZON et al. (2005), in cultivars Gala, Golden, Delicious and Fuji.

Figure 5 - Relation between total soluble solids and total titratable acidity in in strawberries cv. Festival e apple cv. Gala minimally processed, with and without bacterial cellulose, kept at $7{ }^{\circ} \mathrm{C} \pm 2{ }^{\circ} \mathrm{C}$ in $90 \% \pm 5 \%$ relative humidity (RH).

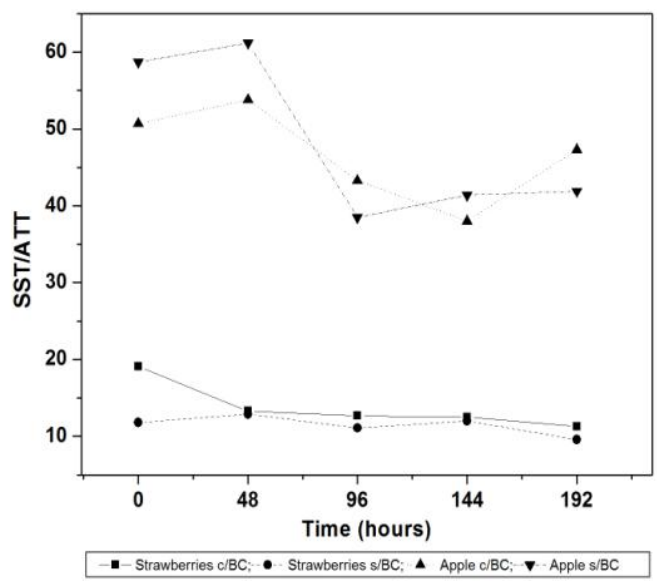

The $\mathrm{pH}$ average values showed significant differences $(\mathrm{p} \leq 0.05)$ in the strawberries and apples in both treatments but the storage time showed statistical significance $(p \leq 0.05)$ only for the former. The $\mathrm{F}$ test corroborates with the $P$ values and showed significance to the predictive ends in 
the time variable to strawberries and in the apples treatments form. The coated strawberries have $\mathrm{pH}$ lower than that found in the pseudo fruits without cover, with initial values of 3.28 and 3.55, what can be explained by the biofilm $\mathrm{pH}$ interference of 3.02, under the fruit $\mathrm{pH}$. During storage, coated strawberries do lower $\mathrm{pH}, 1.52 \%$ in relation to the pseudo fruits without cover, $14.3 \%$. In apples with and without bacterial cellulose, the $\mathrm{pH}$ showed reduction of $4.48 \%$ and $1.8 \%$, respectively, so the cellulose pellicle promoted higher $\mathrm{pH}$ reduction (Figure 6).

Figure 6 - Evolution of the $\mathrm{pH}$ in strawberries cv. Festival e apple cv. Gala minimally processed, with and without bacterial cellulose, kept at $7{ }^{\circ} \mathrm{C} \pm 2{ }^{\circ} \mathrm{C}$ in $90 \% \pm 5 \%$ relative humidity (RH).

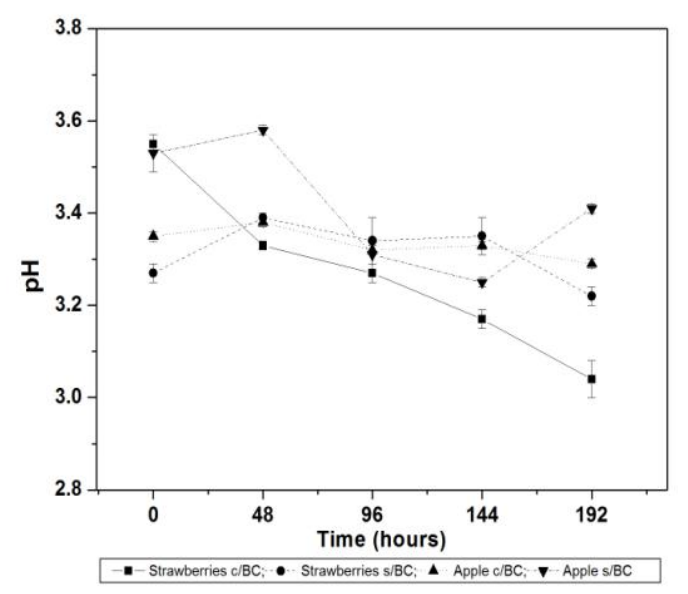

It was observed significant differences $(p \leq 0.05)$ in the average values of firmness, between the treatments and the storage times, in both fruits. The $\mathrm{F}$ test corroborates with the $P$ values and shows statistical differences to the predictive ends in the two variables and analyzed fruits. Strawberries with bacterial cellulose pellicle showed higher firmness, obtained reduction of $18.4 \%$. In these, without cover, the decline was at $46.3 \%$, during the storage. In apple, with bacterial cellulose and without cellulose, the reduction was at $18.8 \%$ and $43 \%$, respective, during the storage period (Figure 7, p.363). This fact suggests that the bacterial cellulose pellicle has been an important factor to delay the dehydration and senescence process of the fruits and, also indicates higher mechanical protection.

In strawberries and apples there were significant differences $(p \leq 0.05)$ between the treatments, in the average values of the phenolic compounds contents. However, during the storage time, this factor do not showed any changes ( $\mathrm{p} \geq 0.05$ ). The $\mathrm{F}$ test corroborates with the $P$ values and shows significant statistical difference to the predictive ends only for the form of treatment variable, to both fruits. In the strawberries with bacterial cellulose, the variation of the phenolic compounds promoted $3.4 \%$ increase. In the pseudo fruits, without cover, the increase was at $4.7 \%$ in the storage time. 
Figure 7 - Evolution of the firmness in strawberries cv. Festival e apple cv. Gala minimally processed, with and without bacterial cellulose, kept at $7{ }^{\circ} \mathrm{C} \pm 2{ }^{\circ} \mathrm{C}$ in $90 \% \pm 5 \%$ relative humidity $(\mathrm{RH})$.

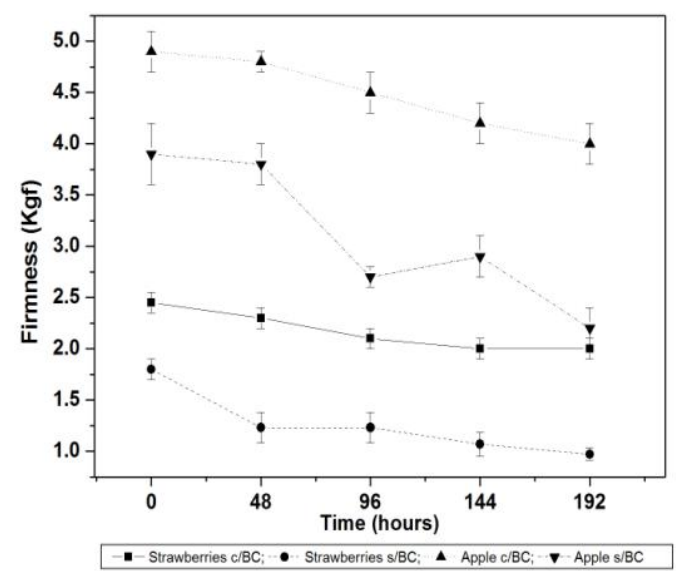

In apples, with or without bacterial cellulose had an increase of $47.6 \%$ and reduction of 13.1\% during the storage period (Figure 8). The bacterial cellulose showed opposite trend between the studied fruits, providing lower increases in the phenolic compounds concentration in the strawberries. The raise can be explained by the induction of the phenolic compounds biosynthesis with the purpose of forming a defense against the stress caused in the process that were submitted the fruits, besides the probable microorganisms attack during storage. According to Moretti (2007), the first physiological responses to stress, caused by the minimum process in the vegetable, are the transient increases in the ethylene evolution and respiratory activity elevation, which can be interconnected with the metabolisms induction in the phenolic compounds and with the tissue healing process.

Figure 8 - Evolution of the phenolic compounds in strawberries cv. Festival e apple cv. Gala minimally processed, with and without bacterial cellulose, kept at $7{ }^{\circ} \mathrm{C} \pm 2{ }^{\circ} \mathrm{C}$ in $90 \% \pm 5 \%$ relative humidity $(\mathrm{RH})$

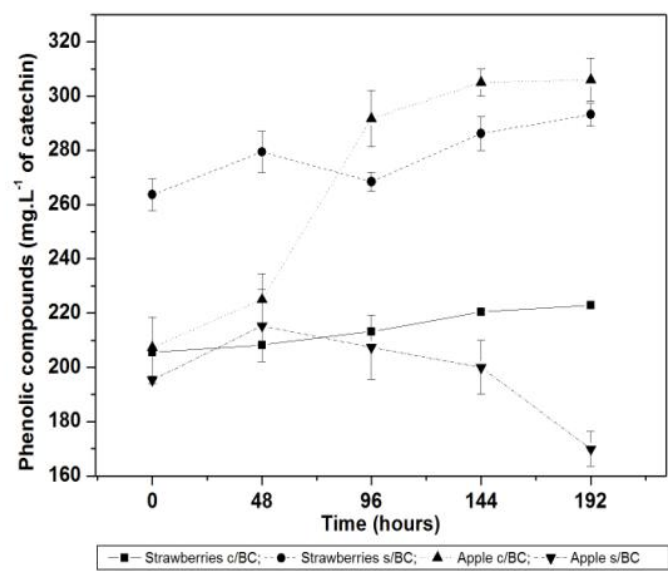


The cover shape promoted significant changes $(\mathrm{p} \leq 0.05)$ in the vitamin $\mathrm{C}$ average values, between the treatments and the storage time, in both fruits. The $\mathrm{F}$ test confirms the $P$ values and shows significance to the predictive ends only to the variable time, in apples. In strawberries, with and without bacterial cellulose cover, the vitamin $\mathrm{C}$ content showed reductions of $27 \%$ and $34 \%$, respectively, in the storage period. With and without bacterial cellulose, apples showed reduction of $22.2 \%$ and $26.3 \%$, during the storage time (Figure 9). The reduction might had happened due to the high enzyme ascorbic acid oxidase activity postharvest, involved in antioxidant reactions that process during the fruits senescence (ISLAN et al., 1993) and due to the vegetables lower capacity to synthesize acid during this period (AGIUS, 2003). Another factor is the occurrence of the oxidation process, when the fruits were exposed to products that contained halogens in your molecule (WRIGHT and KADER, 1997), such as the hypochlorite salts used in the sanitization process. It can be also associate to the organic acids degradation, such as ascorbic acid, during the natural process of maturation and senescence (GARCIA et al., 1998) and, due to the handling during the fruits sanitization, drying, and cover process. The reduction in the ascorbic acid content was also verified by CALEGARO et al. (2002), MALGARIM (2005) and NUNES et al. (2006).

Figure 9 - Evolution of the vitamin $\mathrm{C}$ in strawberries cv. Festival e apple cv. Gala minimally processed, with and without bacterial cellulose, kept at $7^{\circ} \mathrm{C} \pm 2^{\circ} \mathrm{C}$ in $90 \% \pm 5 \%$ relative humidity $(\mathrm{RH})$.

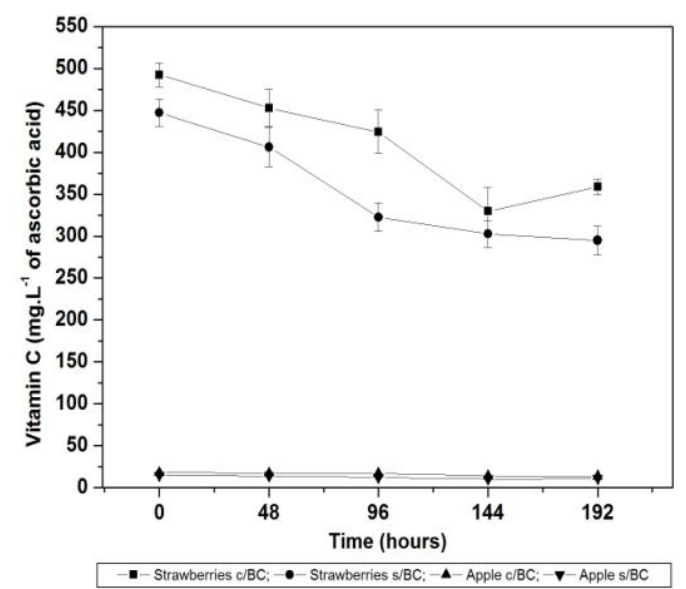

\section{Conclusion}

The bacterial cellulose film was efficient in maintaining the quality of the strawberry cv. Festival and apples cv. Gala minimally processed, in the characteristics of mass loss, soluble solids total, firmness and vitamin $\mathrm{C}$. The lower $\mathrm{pH}$ and phenolic compounds variation was verified in coated strawberries and the ratio SST/ATT shows lower oscillation in apples cover with bacterial cellulose. 
The application of bacterial cellulose biofilm offers using potential in fruits minimally processed, kept by combine methods (biofilm and cooling), maintaining the quality by physical and chemical stability of the products.

\title{
Acknowledgements
}

The authors thank the State University of Ponta Grossa, Technological Federal of Paraná and the Federal of Paraná for the operational infrastructure and to the CNPq for the scholarships awarded.

\begin{abstract}
Resumo
O consumo por alimentos frescos como frutas tem aumentado nas últimas décadas e as minimamente processadas tem vindo a atender essa demanda. O foco deste trabalho é avaliar a aplicação de biofilme de celulose na conservação de frutas minimamente processadas. Foi seguido delineamento fatorial ( $2 \times 5)$, com dois tratamentos (com e sem celulose) e cinco períodos de armazenamento (0, 48, 96, 144 e 192h). Morangos cv. Festival (intacto) e maçãs (quatro fatias) cv. Gala foram utilizados como amostras para a aplicação do biofilme. As variáveis de saída foram massa dos frutos, acidez total titulável (ATT), sólidos solúveis totais (SST), relação SST / ATT, pH, firmeza, compostos fenólicos e vitamina C. Os morangos testados foram comparados com o controle, mantido a massa fresca até 120h, diminuição foi observada em SST (5,8\%), pH (1,5\%), firmeza (18,4\%), vitamina $C(2,2 \%)$ e aumento na concentração de compostos fenólicos $(3,4 \%)$. Maçãs testadas em comparação com o controle mostraram diminuição na perda de peso (10,5\%), aumento na ATT $(15,6 \%)$ de SST (8,1\%), relação SST / ATT (6,7\%), firmeza $(18,8 \%)$ e vitamina C (22,2 \%). A celulose bacteriana foi eficiente na manutenção da qualidade dos morangos e maçãs nos atributos de qualidade da massa fresca, ATT, SST, firmeza e vitamina $C$, como um conservante natural. A aplicação de biofilme de celulose bacteriana oferece potencial de uso nas frutas minimamente processadas, mantidas por métodos combinados (biofilme e refrigeração), mantendo a qualidade pela estabilidade física e química dos produtos.
\end{abstract}

Palavras-chave: morango; maçã, celulose bacteriana; qualidade

\section{References}

AGIUS F.; GONZÁLEZ-LAMONTHE, R.; CABALLERO J. L.; MUNÕZ-BLANCO, J.; BOTELLA, M. A.; VALPUESTA, V. Engineering increased vitamin C levels in plants by overexpression of a D-galacturonic acid reductase. Nature Biotechnology, v. 21, n. 2, p. 177-181, 2003. D.O.I:10.1038/nbt777

BRASIL. Instrução Normativa $n^{\circ}$ 1, de 7 jan. 2000, do Ministério da Agricultura. Diário Oficial da União, Brasília, n. 6, 10 jan. 2000. Seção I, p. 54-58.

CALEGARO, J. M.; PEZZI, E.; BENDER, R. J. Utilização de atmosfera modificada na conservação de morangos em pós-colheita. Pesquisa Agropecuária Brasileira, Brasília, v. 37, n. 8, p1- 6, 2002.

CORDENUNSI, B.R.; NASCIMENTO, J.R.O.; LAJOLO, F.M. Physico-chemical changes related to quality of Five strawberry fruit cultivars during cool-storage. Food Chemistry,v. 83, n.2, p.167-173, 2003. D.O.I:10.1016/S03088146(03)00059-1 
COX, H.E.; PEARSON, D. — The chemical analysis of foods. London, Churchill, 1962. pp. 309

CHITARRA, M.I.F.; CHITARRA, A.B. Pós-colheita de frutas e hortaliças: fisiologia e manuseio. $2^{\text {a }}$.edição Lavras: UFLA, 2005.

GARCIA, M. A.; MARTINO, M. N.; ZARITZKY, N. E. Plasticized Starch-Based Coatings to Improve Strawberry (Fragaria $x$ Ananassa) Quality and Stability. Journal of Agricultural and Food Chemistry, v. 46, p. 3758-3767, 1998. D.O.I:10.1016/S0308-8146(03)00059-1

GARCIA, L. C. Aplicação de coberturas comestíveis em morangos minimamente processados. Campinas, 2009, Dissertação (Mestre em Engenharia de Alimentos). Universidade Estadual de Campinas.

ISLAN, M. N.; COLON, T. VARGAS, T. Effects of prolonged solar exposure on the vitamin C contents of tropical fruits. Food Chemistry, v 48, p.75-78, 1993. D.O.I.:10.1016/0308-8146(93)90224-4

MALGARIM, M. B.; CANTILLANO, R. F. F.; COUTINHO, E. F. Sistemas e condições de colheita e armazenamento na qualidade de morangos cv. Camarosa. Revista Brasileira de Fruticultura, v. 28, n.2, 2006. D.O.I.:10.1590/S010029452006000200007

MALGARIM, M. B. Tratamentos pré e pós-colheita em citros, pêssego e morango produzidos no Rio Grande do Sul. Pelotas, 2005, 121f. Tese (Doutorado em Fruticultura de Clima Temperado) - Faculdade de Agronomia Eliseu Maciel. Universidade Federal de Pelotas.

MATEOS, S. B. Pele descartável. 2007. Disponível em:

<http://www.cni.org.br/produtos/diversos/src/rev44_tecnologia.pdf> Acesso em 07/05/2010.

MORETTI, C. L. Panorama do Processamento Mínimo de Hortaliças. In: MORETTI, C. L. (Ed.). Manual de Processamento Mínimo de Frutas e Hortaliças, SEBRAE, Brasília, p.27-40, 2007.

NUNES, M. C. N. BRECHT J. K., MORAIS A. M. M. B e SARGENT, SA. Physicochemical changes during strawberry development in the Field compared with those that occur in harvested fruit during storage. Journal of Science Food Agriculture, v. 86, p. 180-190, 2006. D.O.I.:10.1002/jsfa.2314

PACHECO, Juan Luis Chávez; YEE, Suri Martinez; ZENTELLA, Martha Contreras; MARVÁN, Edgardo Escamilla. Celulosa Bacteriana en Gluconacetobacter xylinum: Biosíntesis y Aplicaciones. Revista Especializada en Ciencias Químico-Biológicas, vol.7, n.1, p. 18-25. 2004.

PELAYO, C.; EBELER, A.E.; KADER, A.A. Postharvest life and flavor quality of three strawberry cultivars kept at $5^{\circ} \mathrm{C}$ in air or air $+20 \mathrm{KPa} \mathrm{CO}_{2}$. Postharvest Biology and Technology, v. 27, p. 171-183, 2003. D.O.I.:10.1016/S09255214(02)00059-5

RIZZON, L. A.; BERNARDI, J. MIELI, A. Caracterísitcas analíticas dos sucos de maçã Gala, Golden Delicious e Fuji. Ciência e Tecnologia de Alimentos, v. 25, n.4, p.750-756, 2005. D.O.I.:10.1590/S0101-20612005000400020

SANTANA, A. OKAMOTTO, P.T.; BARBOZA, L.C.; FIGUEIREDO, L. C; GRACIOSO, F.; ROSSITER, R.; PAULA, J.; MAYANA, P.; GALLUCCI, L.; MAURICIO, M.; GIDRA, G.; CUNHA, R.D. Hortaliças minimamente processadas. Estudos de mercado SEBRAE/ESPM 2008. Relatório completo. Série Mercado. p.1-174, 2008.

SINGLETON, V. L.; ROSSI, J.A. Jr. Colorimetry of total phenolics with phosphomolybdic-phosphotungstic acid reagents. American Journal Enology Viticulture, v.16, p.144-158, 1965.

WRIGHT, K. P.; KADER, A. A. Effect of slicing and controlled-atmosphere storage on the ascorbate content and quality of strawberries and persimmons. Postharvest Biology and Technology, v. 10, n. 1, p. 39-48, 1997. D.O.I.:10.1016/S0925-5214(96)00061-0

WU, Sheng-Chi; LIA, Ying-Ke. Application of bacterial cellulose pellets in enzyme immobilization. Journal of Molecular Catalysis B: Enzymatic, v. 54, p.103-108, 2008. D.O.I.:10.1016/j.molcatb.2007.12.021

Submetido por mensagem eletrônica em 28 jan 2011; Revisão final enviada pelos autores em 04 de julho de 2011. 